\title{
Removal of a duodenal cyanoacrylate glue bezoar with a snare and cap-assisted endoscopy
}

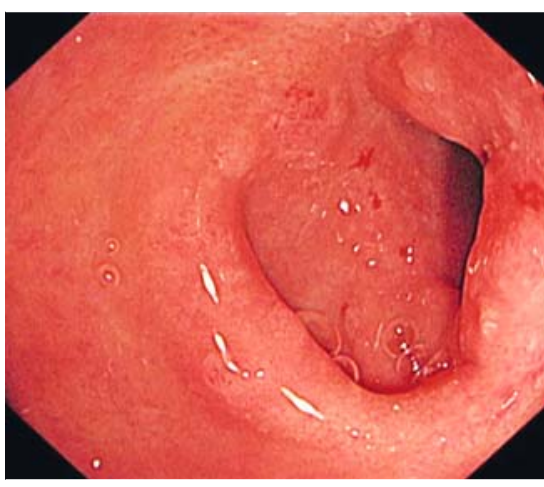

- Fig. 1 Ulcer scar formation with mild stricture and mild malformation at the descending border of the duodenal bulb.

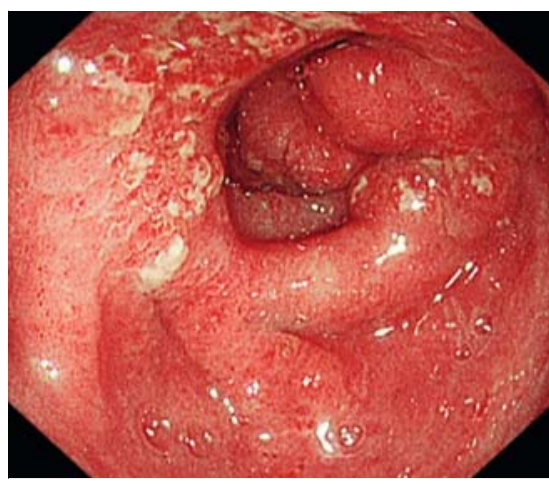

> Fig. 4 Shallow ulcers with peripheral granulation tissue proliferation circling around the outlet of the duodenal bulb.

A 55-year-old man with hepatitis B virusrelated liver cirrhosis presented to the gastroenterology clinic with a 2-week history of melena. Esophagogastroduodenoscopy revealed severe Sarin type 2 gastroesophageal varices with red color signs and ulcer scar with mild stricture at the descending border of the duodenal bulb (>Fig.1). The endoscope was able to pass through freely. Endoscopic variceal obturation (EVO) was performed within two large varices using $2 \mathrm{~mL}$ and $4 \mathrm{~mL}$ respectively of pure $n$-butyl-2-cyanoacrylate tissue glue. Four months later, a tissue glue bezoar of stone-like hardness and hill-like shape, measuring

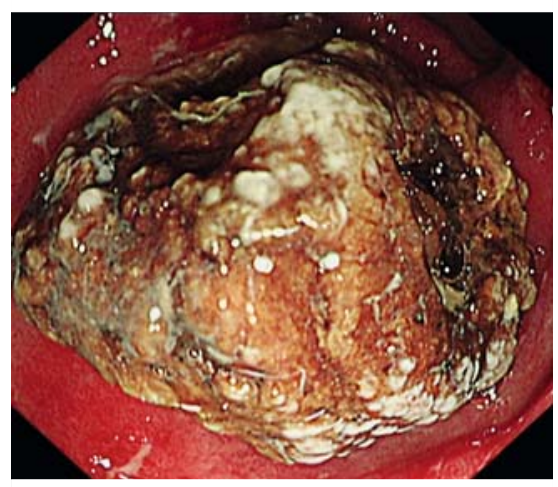

Fig. 2 A tissue glue bezoar measuring about $1.6 \mathrm{~cm} \times 1.5 \mathrm{~cm} \times 0.5 \mathrm{~cm}$ was found detained at the duodenal bulb.

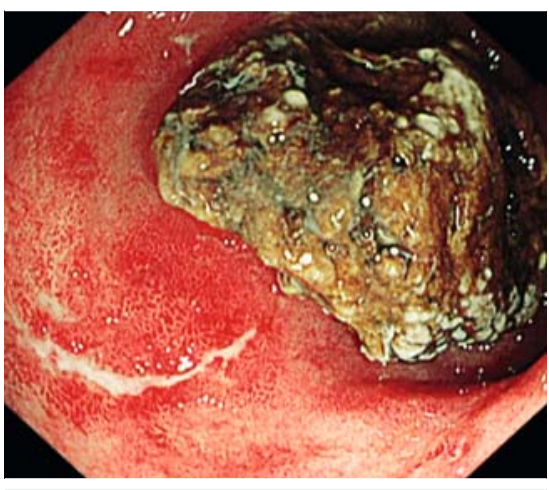

Fig. 3 A shallow ulcer measuring about $0.1 \mathrm{~cm} \times 1.0 \mathrm{~cm}$ was found underneath the bezoar.

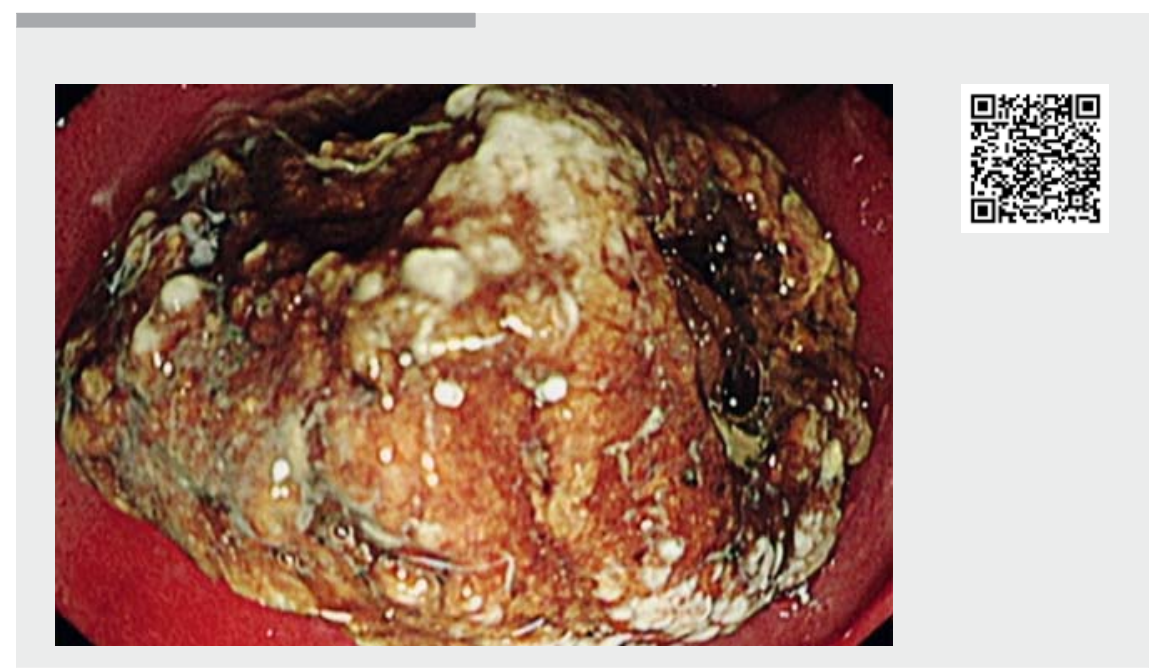

$\checkmark$ Video 1 Removal of a duodenal cyanoacrylate glue bezoar with a snare and cap-assisted endoscopy.

about $1.6 \times 1.5 \times 0.5 \mathrm{~cm}$, was found detained at the duodenal bulb ( $\mathbf{F i g . 2}$ ), along with a circumferential shallow ulcer ( Fig.3). However, there were no special symptoms such as abdominal pain, distention, or the like. Three sequential esophageal variceal ligations were carried out, combined with administration of an oral proton pump inhibitor (PPI). Then, with a transparent cap providing the application point, the bezoar was trapped and fragmented with a wire snare ( $\triangleright$ Video 1 ). The foreign bodies were then aspirated into the transparent cap and retrieved with the aid of the snare. Shallow ulcers were found circling around the outlet of the duodenum bulb, but the bezoar had caused no further injuries (> Fig.4). PPI treatment was continued and a followup endoscopic review 2 months later indicated eradication of the ulcer.

Despite the efficacy of EVO, complications such as needle adhesion, emboliza- 
tion [1], and bacteremia can occur. We report a very rare case of duodenal tissue glue bezoar, probably due to ulcer-related poor compliance of the duodenal bulb. Besides surgical removal, various endoscopic devices and techniques have been described in use for bezoar fragmentation, e.g., basket catheter, electrohydraulic lithotripsy, and others [2]. The use of more advanced devices such as laser [3] and polyfilament snare [4] has also been described. In our patient, successful removal of the tissue glue bezoar was flexibly achieved with easily available equipment: a polypectomy snare and cap-assisted endoscopy [5].

Endoscopy_UCTN_Code_CPL_1AH_2AC

\section{Competing interests}

The authors declare that they have no conflict of interest.

The authors

\section{Meixing Sun, Shuru Pan, Yanpin Liang. Xiuqing Wei}

Department of Gastroenterology, the Third Affiliated Hospital of Sun Yat-Sen University

\section{Corresponding author}

\section{Xiuqing Wei, MD, PhD}

Department of Gastroenterology, The Third Affiliated Hospital of Sun Yat-sen University, 600 Tianhe Road, Guangzhou 510630 , Guangdong Province, P.R. China

Fax: +86-20-85253336

weixq@mail.sysu.edu.cn

\section{References}

[1] Wei XQ, Gu HY, Wu ZE et al. Endoscopic variceal ligation caused massive bleeding due to laceration of an esophageal varicose vein with tissue glue emboli. World J Gastroenterol 2014; 20: 15937-15940

[2] Tseng YJ, Ding WQ, Zhong L et al. Friend or foe: an unusual case of small intestinal mass. Endoscopy 2019; 51: E156-E157

[3] Grande G, Manno M, Zulli C et al. An alternative endoscopic treatment for massive gastric bezoars: Ho:YAG laser fragmentation. Endoscopy 2016; 48 (Suppl. 01): E217

[4] Kurt M, Posul E, Yilmaz B et al. Endoscopic removal of gastric bezoars: an easy technique. Gastrointest Endosc 2014; 80: 895896

[5] Sanchez YA, Kaltenbach T, Yamamoto $\mathrm{H}$ et al. The endoscopic cap that can (with videos). Gastrointest Endosc 2012; 76: 169178.e2
Bibliography

Endoscopy 2021; 53: E219-E220

DOI 10.1055/a-1244-9779

ISSN $0013-726 \mathrm{X}$

published online 11.9.2020

(c) 2020. Thieme. All rights reserved.

Georg Thieme Verlag KG, Rüdigerstraße 14, 70469 Stuttgart, Germany

\section{ENDOSCOPY E-VIDEOS}

https:/|eref.thieme.de/e-videos

口回 Endoscopy E-Videos is a free

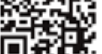
access online section, reporting on interesting cases and new techniques in gastroenterological endoscopy. All papers include a high quality video and all contributions are freely accessible online.

This section has its own submission website at https://mc.manuscriptcentral.com/e-videos 